\title{
Are Communities Benefiting from Land Reform Models? Investigating Forest-Based Public-Private Partnerships in Selected Beneficiary Communities in South Africa
}

\author{
R.P. TSHIDZUMBA ${ }^{\mathrm{a} *}$ P.W. CHIRWA ${ }^{\mathrm{a}}$ F.D. BABALOLA ${ }^{\mathrm{ab}}$ \\ ${ }^{a}$ Forest Science Postgraduate Programme, Department of Plant and Soil Sciences, Faculty of \\ Natural and Agricultural Sciences, University of Pretoria, 5-15 Plant Sciences Complex, \\ Corner of Lynwood Rd and Roper St, Hatfield, Pretoria, 0028, South Africa \\ ${ }^{\mathrm{b}}$ Department of Forest Resources Management, University of Ilorin, Ilorin, Nigeria
}

Email: phillipmgf@yahoo.com, paxie.chirwa@up.ac.za, babalola.fd@unilorin.edu.ng

\begin{abstract}
Land reform in South Africa, like in other developing countries with a history of land grab and people's displacement, is an issue of serious contestation. The study therefore assessed the accrual of benefits to claimant communities from the two forest-based public-private partnership (PPP) land reform models (Sales and Leaseback, and Community Managed Enterprise). A random sampling technique was used to select 140 and 175 households in Amabomvini and Cata communities in Kwazulu Natal and Eastern Cape Provinces, respectively. Ordinal logistic regression, descriptive analysis, including frequencies and Chisquare were computed to process the data using Statistical Package for Social Sciences (SPSS) software (Version 20). From the results, the socioeconomic status of Cata household beneficiaries improved compared to that of Amabomvini after the implementation of forestbased PPP land reform models. Both communities were concerned about non-implementation of post-settlement support by the government upon settlement of their land claims. Tailor-made leadership and business management training should be designed for the CPA committee members and trustees in order to achieve mutual distribution of benefits to all beneficiaries
\end{abstract}

Keywords: Benefit accrual, Benefit-sharing mechanisms, Community beneficiaries, Community Managed Enterprise, Sales and Leaseback, Socioeconomic status

\section{INTRODUCTION}

Land reform in South Africa, like in other developing countries with a history of land grabs and people's displacement, is an issue of serious contention (Sikor and Müller 2009). In South Africa during the era of the apartheid government, the black population which consitiuted the majority of race in the country were disposed of their land. This dispossession was chiefly targeted at productive arable arable land owned by the black population in order to steer 
economic development that was designed to soley benefit the white minority race (DLA, 1997; Britton 2006). Consequently, the majority of the black population became landless in their country of birth, leading to great imbalance in land ownership in the country with the white population accessing control of more than $80 \%$ of quality arable land, while the majority of the black people were left disgruntled and owning less than 15\% of poor land (Rumney 2005).

The 1994 inauguration of the post-apartheid government in South Africa necessitated an immediate and much needed shift in policy direction in order to address socioeconomic imbalances in the country through a Reconstruction Development Programme (RDP) (Clarke 2008, Hall 2004, Lahiff et al. 2012). This programme was aimed at improving the socioeconomic status of previously disadvantaged race (black) under the apartheid government (ANC 1994, RSA 1994). In the same vein, the Land Reform Programme was introduced, and aimed at recognizing the land access and ownership rights of previously disadvantaged people (Clarke 2008, Clarke and Isaacs 2005, DWAF 2005, Hall 2009, Ham and Chirwa 2007, McMenamin 2009, Van Loggerenberg and Mandondo 2008). In particular the land reform programme targeted the segment of South African society that was removed from their land under the Native Land Act No. 27 of 1913 of the previous oppressive regime (De Wet 1997, Lahiff 2007a, Makhanye 2013, Pepeteka 2013).

In line with the national government's programme, all sectors of the national economy, including the forest sector, have an obligation to develop transformation programmes under Broad-Based Black Economic Empowerment (BBBEE) to redress the injustice of the past, by providing facilitated assistance and opportunity for the previously disadvantaged people. Based on this directive, the Department of Agriculture, Forestry and Fisheries (DAFF) strategically developed the Forestry Sector Transformation Charter (FSTC) (DWAF 2007). This Charter was aimed at improving the livelihoods of previously disadvantaged communities through the provisioning of several forest business opportunities (Clarke 2008, Clarke and Isaacs 2005, DWAF 2005, Hall 2009, Ham and Chirwa 2007, McMenamin 2009, Van Loggerenberg and Mandondo 2008). In conforming to the directives of the Charter, the South African forest industry initiated different land restitution programmes. These restitution programmes eventually led to the implementation of several post-settlement forest-based public-private partnership models with a focus on improving the livelihoods of claimant communities (Aliber and Maluleke 2010). 
However, the issue of the sustainability of forestlands transferred to claimants' communities remains a prioritized concern (Dlomo and Pitcher 2003). This concern is drawing forestry stakeholders' attention to the concept of public-private partnership as a way of opening up opportunities to the claimant communities, while also committing to the sustainability of forest production on the land returned to the community beneficiaries (Godsmark 2008). According to Shaheen and Khan (2008), PPP is defined generally "as a government service or private business venture, which is funded and operated through a partnership between government and one or more private companies". In the same vein, it is noteworthy highlighting that both forestry industry and government embraced this approach to resolve the rampant land claim disputes as well as ensuring the empowerment of claimant beneficiaries (Ojwang, 2000). Additionally, the integration of local communities in this partnership arrangement provided valuable opportunities towards ensuring equitable distribution of benefits amongst the beneficiaries. Furthermore, the significance of pursuing PPP in order to resolve current and future societal challenges in a more coordinated approach have been emphasized (Hedman et al. 2008).

Several studies in South Africa have investigated the sustainability and impacts of land reform models in the agriculture and forestry sectors (Chirwa et al. 2015, Mayers and Vermeulen 2002, Van Loggerenberg and Mandondo 2008). These studies have focused solely on identifying the type of models that are preferred by the land beneficiaries (the claimant communities). For instance, it has been found that the majority of the implemented public-private partnership initiatives have not delivered the anticipated benefits to the land claimants, such as employment opportunities and technical skills through mentorship and decision-making. In forestry, quite a number of the claimant communities preferred the joint venture model to other models, due to its ability to transfer land ownership and management skills to the beneficiaries (Chirwa et al. 2015). However, these studies failed to explicitly assess whether other benefits from land settlement models were delivered to claimant communities. In particular, the socioeconomic analysis of the claimant communities, in relation to promised benefits stated in partnership agreements, have remained largely uninvestigated.

This study investigated two forest-based post-settlement support partnership models, namely the Sales and Leaseback model (SLB) and the Community Managing own land model, which is referred to in this study as the Community Managed Enterprise model (CME). As described in Makhathini (2010), the SLB model was the first to be used in the South African forestry 
industry as an approach to expedite the land claim settlement process, and to ensure timber production sustainability (i.e. under land restitution) on claimed forest plantations. The model's lease agreement ascribed various benefits to the land claimants, ranging from employment, bursary funding, lease agreement rental, stumpage fee, mentorship (extension services) and entrepreneurial development opportunities. On the other hand, the CME model is characterized by exclusive responsibility put on community beneficiaries to manage their land and empower themselves socioeconomically, with the assistance of non-governmental or civil society organizations as well as local municipality. However, as highlighted by Godsmark (2008), the CME model requires high levels of post-settlement support in order for the beneficiaries to achieve its intended objectives. This view is in line with that of Greijmans et al. (2014), who suggested that there are many factors that often limit the viability of this model, which include a lack of government support through non-implementation of policies. Thus, this study was aimed at assessing the accrual of the benefits from forest-based public-private partnership (PPP) land reform models to claimant communities. The study investigated the two land reform models as used in Amabomvini and Cata communities located in the Kwa-Zulu Natal and Eastern Cape Provinces of South Africa, respectively. The study specifically tested the hypothesis that the accrual of socioeconomic benefits to land claimant communities do not differ between the two forest-based land reform models.

\section{RESEARCH METHODOLOGY}

\subsection{Description of the study areas}

The study was conducted at the Amabomvini community, situated in the Kranskop area in the Kwa-Zulu Natal (KZN) Province and the Cata community, situated in the Keiskemmahoek area (along the Amathole mountain range) in the Eastern Cape Province of South Africa (Figure 1). These two communities were selected because they are beneficiaries of land transferred through restitution. Furthermore, the two communities have been engaged in forestry operations under forest-based land reform models, which include the Sales and Lease Back (SLB) model, managed by a Trust in Amabomvini, and the Community Managed Enterprise (CME) model, managed by a non-governmental organisation (NGO) at Cata for a period of more than five years. Additionally, the Amabomvini community received their land back in the year 2008 and subsequently reached an agreement to lease back the land to the forestry company for two rotations (20 years) under a Community Trust (Table 1). 
'Consequently, the Amabomvini land claimant beneficiaries through Community Trust (CT) were assisted to register a forestry contracting company named Ingudle. In line with the SLB agreement, Ingudle was therefore contracted to manage all silvicultural operations in the plantation, with the mentorship provided by the forest private company's professional forester. In addition to the SLB partnership agreement, the private company leasing back the land from the land claimant beneficiaries had an obligation to provide a series of benefits to the beneficiaries. These included provisioning of bursary funding, employment creation, entrepreneurship development, income generation through payment of annual rental consisting of $7 \%$ of the value of planted area to the community trust and $2 \%$ of the stumpage fee of harvested timber (Makhathini, 2010; Muller, 2011; Sustainable Development Report, 2011).

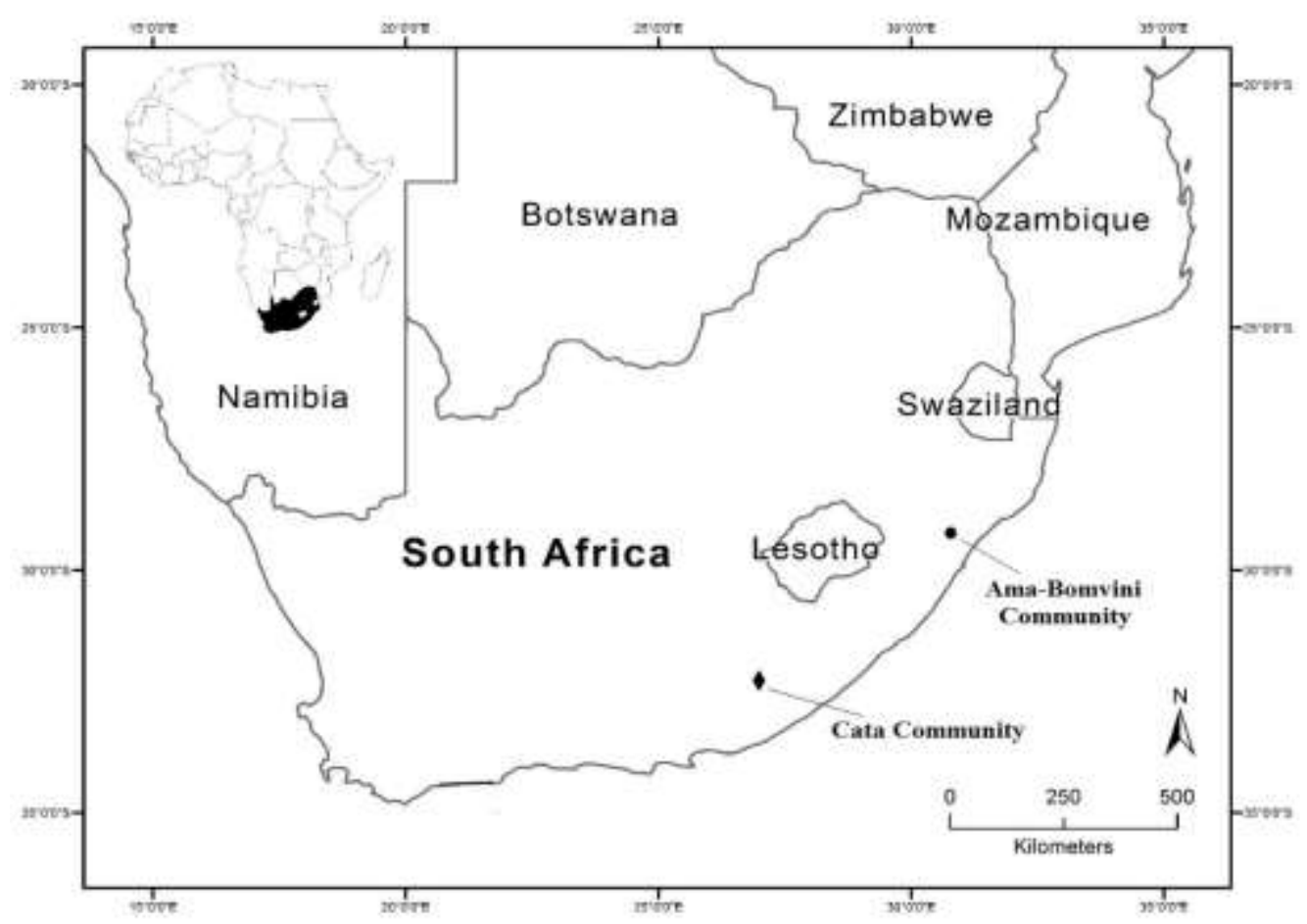

FIGURE 1: The South African map depicting the study areas in selected provinces

On the other hand, the Cata community received their land back in 2002 and subsequently opted to pursue the management of the land by themselves under the leadership of the Trust, which later was changed into the Communal Property Association (CPA). Most importantly, the CPA is the legal entity that represent all the land claimant beneficiaries as per the beneficiaries register upon land claim settlement. However, the Cata community works closely with the Border Rural Committee (BRC), which is an NGO that provides mentorship, sourcing of funding and other support. Most importantly, the CME forest-based land reform partnership 
model adopted in Cata community involved an agreement where the land claimant beneficiaries' opted to manage the land transferred to them with professional assistance from the non-governmental organisation (BRC) and government in the form of local municipality (Amahlati). In this case, the role of the NGO was to provide the project with technical and financial management as well as fundraising expertise, with the local municipality's responsibility being to provide assistance with regard to project funding in order to ensure sustainable management of forestry, agriculture and recreation and tourism projects initiatives.

TABLE 1: Information defining both selected community beneficiaries in this study

\begin{tabular}{lll}
\hline Information & Amabomvini & Cata \\
\hline Land claim settlement & 2008 & 2002 \\
Commencement of partnership & 2008 & 2002 \\
Partner type & Private company & NGO \\
Duration of the agreement & 20 years & Not specified \\
Forest-based land reform model adopted & SLB & CME \\
Registered Entity & Community Trust & CPA \\
Province & Kwa-Zulu Natal & Eastern Cape \\
Municipality & Umvoti & Amahlathi \\
Language & Zulu & Xhosa \\
Locality & Rural & Rural \\
Geographic location & $29^{\circ} 5{ }^{\prime} 26.38^{\prime \prime}$ S & $32^{\circ} 35^{\prime} 20.90^{\prime \prime}$ S \\
& $30^{\circ} 56^{\prime} 48.22^{\prime \prime} \mathrm{E}$ & $27^{\circ} 77^{\prime} 19.46^{\prime \prime} \mathrm{E}$ \\
Number of Household beneficiaries & 220 & 320 \\
Size of the claimed land & 2038 ha & 650 \\
Size of the land leased back & 1515 ha & 0 ha \\
Registered company & Ingudle & None \\
\hline
\end{tabular}

\subsection{Sampling and data collection}

In this study, a mixed-mode research design approach was used (Bhattacherjee 2012). This approach was chosen to ensure the representativeness of the responses from the respondents (Kelley et al. 2003). Additionally, probability sampling was chosen to avoid sampling bias. Specifically, simple random sampling was used in both selected areas, while the sampling size was determined using the approach of Krejcie and Morgan (1970). In this approach, the total population or number of household beneficiaries in the study communities was considered for sample size determination. Consequently, the following formula was used:

$$
\mathrm{S}=\frac{X^{2} N P(1-P)}{d^{2}(N-1)+X^{2} P(1-P)}
$$


where $S=$ Required Sample size, $X=Z$ value (e.g. 1.96 for $95 \%$ confidence level), $N$ $=$ Population Size, $P=$ Population proportion (expressed as decimal) (assumed to be 0.5 (50\%) and $d=$ Degree of accuracy (5\%), expressed as a proportion (0.05), which is the margin of error. In the Amabomvini community, 140 households were randomly sampled while 175 were sampled in the Cata community. The randomization to identify households to be interviewed was conducted using the beneficiaries register list provided by the Trust (Amabomvini community) and CPA (Cata community). This was intended to ensure that the households that were to participate in the survey actually represented the land beneficiaries.

\subsection{Household questionnaire}

The heads of the households that benefited from land transfer in each community were interviewed using a generic structured questionnaire. The questionnaire contained questions regarding the type of socioeconomic benefits that the household beneficiaries in both communities received due to the forest-based land reform partnership model adopted respectively. In order to maintain the originality and clear understanding of the questions to all the respondents in the two study areas, and for ease of administration of the questionnaire, it was translated into the local languages spoken in the two communities. Thus for the Amabomvini community the questionnaire was translated into Zulu and into Xhosa for the Cata community. A five-point likert scale approach was used in designing the questionnaire (Allen and Seaman 2007). To ensure that the questionnaire was developed appropriately and that it captured the whole scope intended for the study, pre-testing with the Amahlongwa community beneficiaries was conducted in Kwa-Zulu Natal, prior to the actual administration in the selected communities. For harnessing in-depth information about the socioeconomic benefits accrued from the forest-based PPP land reform models implemented by both communities, focus group discussions were conducted with the trustees in Amabomvini, and CPA committee members in Cata, respectively.

\subsection{Statistical data analysis}

An ordinal logistic regression (PLUM Procedure) model was computed to estimate the odds of accrued benefits (employment, financial, bursary, nominated as trustee and technicial skills) from the forest-based PPP land reform partnership arrangement on the socioeconomic status (SES) level of household beneficiaries. The depedent variable responses were ordered with value 2 = "high SES level", 1 = "middle SES level" and $0=$ "low SES level". However, the 
dichotomous independent variables were dummy coded into value $0=$ "Yes" if household beneficiaries accrued benefits and $1=$ "No" if household beneficiaries did not accrue benefits (Table 2). The logit model equation used in the analysis is as follows:

$\operatorname{In} \frac{\mathrm{P}}{(1-\mathrm{P})}=\alpha+\beta_{1} X_{1}+\beta_{2} X_{2}+\beta_{3} X_{3}+\ldots+\beta_{k} X_{k}$

From the equation, $\beta$ denotes the intercept of explonatory variable on the perceived socioeconomic status level of the household beneficiaries, $\mathrm{X}$ denotes the explanatory variables (accrued benefits) used in the model to predict the effect on dependent variable. $\mathrm{P}$ is the probability of household experiencing change on socioeconomic status level and ( $\mathrm{P} / 1-\mathrm{P})$ denotes the odds ratio of household experiencing change on socioeconomic status level. In addition to ordinal logistic regression analysis, descriptive analysis, including frequencies and Chi-square to test the relationship between the responses on benefits accrued by the household respondents in two communities from the forest-based land reform models at $\mathrm{p}<0.05$, were computed using Statistical Package for Social Sciences (SPSS) software (Version 20).

TABLE 2: Explanatory variables used in ordinal logistic regression analysis

\begin{tabular}{cc}
\hline Explanatory Variables $^{\mathrm{a}}$ & Frequency $(\mathrm{n}=315)$ \\
\hline Employment benefit & \\
Yes $=0$ & 127 \\
No $=1$ & 188 \\
Financial benefit & \\
Yes $=0$ & 194 \\
No $=1$ & 121 \\
Bursary benefit & 27 \\
Yes $=0$ & 288 \\
No $=1$ & \\
Yes $=0$ & 35 \\
No $=1$ & 280 \\
Technical skills benefit & \\
Yes $=0$ & 52 \\
No $=1$ & 263 \\
\hline
\end{tabular}

${ }^{a}$ Household accrued benefits from the forest-based partnership arrangement

\section{RESULTS}

\subsection{Characteristics of the households}

Table 3 portrays characteristics of the households within the Amabomvini and Cata communities, respectively. From both communities, there were more female respondents, accounting for $58.6 \%$ in Amabomvini and $64.6 \%$ in Cata. The percentage of the household respondents in each age group also differed between the two communities. In particular, the youth (18-35) respondents in both communities were low, accounting for $11.4 \%$ in 
Amabomvini and $7.4 \%$ in Cata. Moreover, $68.6 \%$ of the respondents were over 55 years in Cata, compared to $54.3 \%$ in Amabomvini. There were significant differences in marital status ( $\mathrm{p}<0.001$ ), with more respondents married in Cata (52.6\%) than in Amabomvini (42.9\%). Regarding the education level, the majority of the respondents attended primary school as the highest education in both communities but more respondents had low literacy levels in Amabomvini (33.6\%) compared to Cata (14.9\%). Only $30.3 \%$ of the respondents in Cata were unemployed compared to $42.9 \%$ in Amabomvini. Furthermore, the individual ownership of land, outside the land transferred to both communities under land restitution, accounted for $1.4 \%$ in Amabomvini and $9.7 \%$ in Cata, respectively.

TABLE 3: Demographic description of study communities

\begin{tabular}{lcc}
\hline Characteristics & Proportion of respondents (\%) in two communities \\
\cline { 2 - 3 } & Amabomvini & Cata \\
& $(\mathrm{n}=140)$ & $175)$ \\
\hline Gender & & 36.6 \\
Male & 41.4 & 63.4 \\
Female & 58.6 & 7.4 \\
Age Category (Year) & & 24 \\
18-35 & 11.4 & 68.6 \\
36-55 & 34.3 & 19.4 \\
Over 55 & 54.3 & 52.6 \\
Marital Status & & 8.6 \\
Single & 44.3 & 19.4 \\
Married & 42.9 & 14.9 \\
Divorce & 0.7 & 46.3 \\
Widow/widower & 12.1 & 36.0 \\
Highest Level of Education & & 2.9 \\
Not educated & 33.6 & \\
Primary & 45.7 & 30.3 \\
Secondary & 20.0 & 69.7 \\
Tertiary & 0.7 & 9.7 \\
Employment Status of Household Member & & 90.3 \\
Not Employed & 42.9 & \\
Employed & 57.1 & \\
Private Land Ownership & & \\
Yes & 1.4 & \\
No & 98.6 & \\
\hline
\end{tabular}

\subsection{Types of accrued benefits to beneficiaries}

Table 4 presents the accrued benefits to household beneficiaries in both Amabomvini and Cata communities, as a result of the adoption of the forest-based land reform model. Generally, the results showed that households in Cata acquired more of the tested benefits than those from Amabomvini. The results showed a statistical significant relationship $(p<0.001)$ in all the benefits accrued to households from both communities. About $32.0 \%$ of the respondents in Cata strongly agreed to employment accrual compared to only $4.3 \%$ in Amabomvini. Regarding employment opportunities created through the partnership models, the Amabomvini 
trustees emphasized during the FGD, the fact that majority of the beneficiaries showed no interest in working in the forest, more especially the youth. On the other hand, the Cata CPA committee members indicated that the multipronged project approach including forestry, agriculture and tourism projects significantly improved employment opportunities. Yet, contrary to the trustees' view, the Amabomvini beneficiaries claimed that the trust's forestry contracting company considered majority of people who are not beneficiaries for employment opportunities. Furthermore, about $25 \%$ of the respondents in Cata indicated that they have received technical skills training as compared to $5.0 \%$ of respondents in Amabomvini. Regarding marginal technical skills accrual by Amabomvini beneficiaries, FGD findings confirmed that those managing the CT's forestry contracting company (Ingudle) are the ones prioritized as they work closely with the private company that leased the land.

Additionally, respondents in Cata revealed that they had more opportunities to participate in the Community Property Association (15.4\%) than those in Amabomvini (5.7\%). On financial benefits received from the partnership model, responses from the communities follow a similar pattern; about $66.4 \%$ and $57.7 \%$ of the respondents in Amabomvini and Cata respectively indicated that they have benefited financially in a substantive manner. However, FGD results in Amabomvini revealed contrary views between the trustees and the beneficiaries with the trustees indicating that all the beneficiaries accrued a once-off financial benefit of R2000 since inception of the SLB partnership model. On the same note, other beneficiaries not serving as trustees emphasized that due to the elite factor within the household structures as well as lack of transparency from the trustees' side regarding financial benefit-sharing mechanisms, not all beneficiaries accrued financial benefits.

Similarly, $32.0 \%$ and $31.4 \%$ of the respondents disagreed to receipt of financial benefits in Cata and Amabomvini respectively. Substantive dissimilarity, with respect to financial benefits, lay with those that neither agreed nor disagreed, which was $10.3 \%$ for Cata and $2.1 \%$ for Amabomvini. On bursary awards, the majority of respondents (92.8\% for Amabomvini and $73.2 \%$ for Cata) in both communities indicated that they did not receive any bursary. For example, the Amabomvini trustees indicated that only four youth beneficiaries were awarded bursaries to study towards professional qualifications, but all of them eventually dropped out. On the other hand, the Cata CPA members indicated that funding for skills training in their community has been sourced with the assistance of BRC. Furthermore, they emphasized that this funding was prioritized for financial and technical skills training of those members in the 
managerial positions of the community projects. Findings from the FGD pointed out that majority of the beneficiaries from Amabomvini community did not accrue all the benefits set out in the SLB partnership agreement to their household.

TABLE 4: Types of benefits accruing to the community from the forest-based land reform models

\begin{tabular}{|c|c|c|c|c|c|c|}
\hline \multirow[t]{2}{*}{ Benefits } & \multirow[t]{2}{*}{ Responses } & \multicolumn{2}{|c|}{$\begin{array}{l}\text { Proportion of respondents }(\%) \text { in } \\
\text { two communities }\end{array}$} & \multicolumn{3}{|c|}{ Inferential statistics } \\
\hline & & $\begin{array}{c}\text { Amabomvini } \\
(\mathrm{n}=140)\end{array}$ & $\begin{array}{c}\text { Cata } \\
(\mathrm{n}=175)\end{array}$ & $\chi^{2}$ & $\mathrm{df}$ & p-value \\
\hline \multirow{5}{*}{$\begin{array}{l}\text { Employment in the } \\
\text { plantation }\end{array}$} & Strongly Agree & 4.3 & 32.0 & & & \\
\hline & Agree & 11.4 & 28.0 & & & \\
\hline & Neither agree nor disagree & 2.9 & 8.6 & 113.927 & 4 & 0.000 \\
\hline & Disagree & 17.1 & 21.7 & & & \\
\hline & Strongly Disagree & 64.3 & 9.7 & & & \\
\hline \multirow[t]{5}{*}{ Financial benefits } & Strongly Agree & 11.4 & 33.1 & & & \\
\hline & Agree & 55.0 & 24.6 & & & \\
\hline & Neither agree nor disagree & 2.1 & 10.3 & 71.533 & 4 & 0.000 \\
\hline & Disagree & 6.4 & 24.0 & & & \\
\hline & Strongly Disagree & 25.0 & 8.0 & & & \\
\hline \multirow[t]{5}{*}{ Bursary } & Strongly Agree & 1.4 & 4.0 & & & \\
\hline & Agree & 2.9 & 8.0 & & & \\
\hline & Neither agree nor disagree & 2.9 & 14.9 & 75.736 & 4 & 0.000 \\
\hline & Disagree & 21.4 & 50.3 & & & \\
\hline & Strongly Disagree & 71.4 & 22.9 & & & \\
\hline \multirow[t]{5}{*}{ Nominated as a trustee } & Strongly Agree & 3.6 & 10.3 & & & \\
\hline & Agree & 2.1 & 5.1 & & & \\
\hline & Neither agree nor disagree & 2.9 & 10.3 & 86.130 & 4 & 0.000 \\
\hline & Disagree & 20.7 & 55.4 & & & \\
\hline & Strongly Disagree & 70.7 & 18.9 & & & \\
\hline \multirow[t]{5}{*}{ Technical skills } & Strongly Agree & 1.4 & 12.6 & & & \\
\hline & Agree & 3.6 & 13.1 & & & \\
\hline & Neither agree nor disagree & 5.7 & 18.3 & 90.632 & 4 & 0.000 \\
\hline & Disagree & 22.1 & 40.0 & & & \\
\hline & Strongly Disagree & 67.1 & 16.0 & & & \\
\hline
\end{tabular}

\subsection{Effect of forest-based land reform initiatives on household socioeconomic status}

Forest-based land reform models were found to have contrasting effects on the socioeconomic status of households in both communities. Results in Table 5 present the effect of the forestbased land reform model initiatives on the socioeconomic status of households prior and post project implementation. There was a significant relationship in the satisfaction responses of the respondents on their household socioeconomic status in the two communities prior $\left(\chi^{2}=\right.$ 35.384, $\mathrm{p}<0.001)$ and post $\left(\chi^{2}=118.654, \mathrm{p}<0.001\right)$ implementation of each forest-based land reform initiative. The satisfaction level of the Amabomvini community respondents' (not at all satisfied) with their household socioeconomic status post-implementation was $65.7 \%$ compared to $51.4 \%$ prior implementation. 
However, the opposite was the case in the Cata community, having acquired their land earlier and deciding to manage it under the CME forest-based land reform model. Majority of the respondents $(32.6 \%)$ from Cata community were not at all satisfied with their household socioeconomic status prior implementation of reform, while in the contrary, fewer respondents (14.3\%) revealed they were not at all satisfied post implementation. Additionally, the Cata respondents' satisfaction level with their household socioeconomic status, slightly increased from $12.6 \%$ prior to $17.7 \%$ post implementation compared to a slight decrease from $7.9 \%$ prior to $2.1 \%$ post implementation of the FBLR model. Findings from the FGD in both communities, highlighted common sentimental trends emphasizing that government has completely failed to provide post-settlement support promised to them upon settlement of the claim. Furthermore, the Amabomvini trustees felt that the failure of government to attend scheduled executive committee partnership meetings substantially compromised their negotiating power.

TABLE 5: Household responses on socioeconomic status prior and post implementation of forest-based land reform models in the two communities

\begin{tabular}{|c|c|c|c|c|}
\hline \multirow[t]{2}{*}{ Responses } & \multicolumn{2}{|c|}{$\begin{array}{c}\text { Prior implementation } \\
\left(\chi^{2}=35.384 ; \mathrm{df}=4 ; \mathrm{p}=0.000^{*}\right)\end{array}$} & \multicolumn{2}{|c|}{$\begin{array}{c}\text { Post implementation } \\
\left(\chi^{2}=118,654 ; \mathrm{df}=4 ; \mathrm{p}=0.000^{*}\right)\end{array}$} \\
\hline & $\begin{array}{l}\text { Amabomvini } \\
(\mathrm{n}=140)\end{array}$ & $\begin{array}{c}\text { Cata } \\
(\mathrm{n}=175)\end{array}$ & $\begin{array}{l}\text { Amabomvini } \\
(\mathrm{n}=140)\end{array}$ & $\begin{array}{c}\text { Cata } \\
(\mathrm{n}=175)\end{array}$ \\
\hline Not at all satisfied & 51.4 & 32.6 & 65.7 & 14.3 \\
\hline Slightly satisfied & 21.4 & 18.3 & 22.9 & 16.0 \\
\hline Neutral & 3.6 & 26.3 & 7.9 & 33.7 \\
\hline Satisfied & 15.7 & 10.3 & 1.4 & 18.3 \\
\hline Very satisfied & 7.9 & 12.6 & 2.1 & 17.7 \\
\hline
\end{tabular}

*The relationship between the responses is statistically significant at $\mathrm{p}<0.001$

\subsection{Respondents' perception of benefits requiring extra attention}

Figure 2 shows various accrued benefits that household beneficiaries of the two communities perceive requires more attention in order to improve distribution to all beneficiairies. The majority of household beneficiaries in both Amabomvini (87.1\%) and Cata (85.1\%) felt that more attention should be focused on the delivery of employment benefit from the plantation. A similar pattern was observed regarding the business exposure benefit (an opportunity provided to the beneficiaries to participate in forest business under mentorship as a result of forest-based land reform partnership model), where $89.2 \%$ of household beneficiaries from Amabomvini and $88.6 \%$ from Cata felt more attention should be focused on the business exposure benefit. Additionally, about $92.9 \%$ of household beneficiaries in Amabomvini valued education support compared to $81.1 \%$ in Cata. Similarly, $89.9 \%$ of the household beneficiaries 
from Amabomvini required the timber growing exposure benefit to be given attention in comparision to $79.4 \%$ from Cata. Majority household beneficiaries indicated that land management knowledge should be prioritized, with 95.5\% from Amabomvini and 82.9\% from Cata.

甲Ama-Bomvini (Yes) ㅁata (Yes)

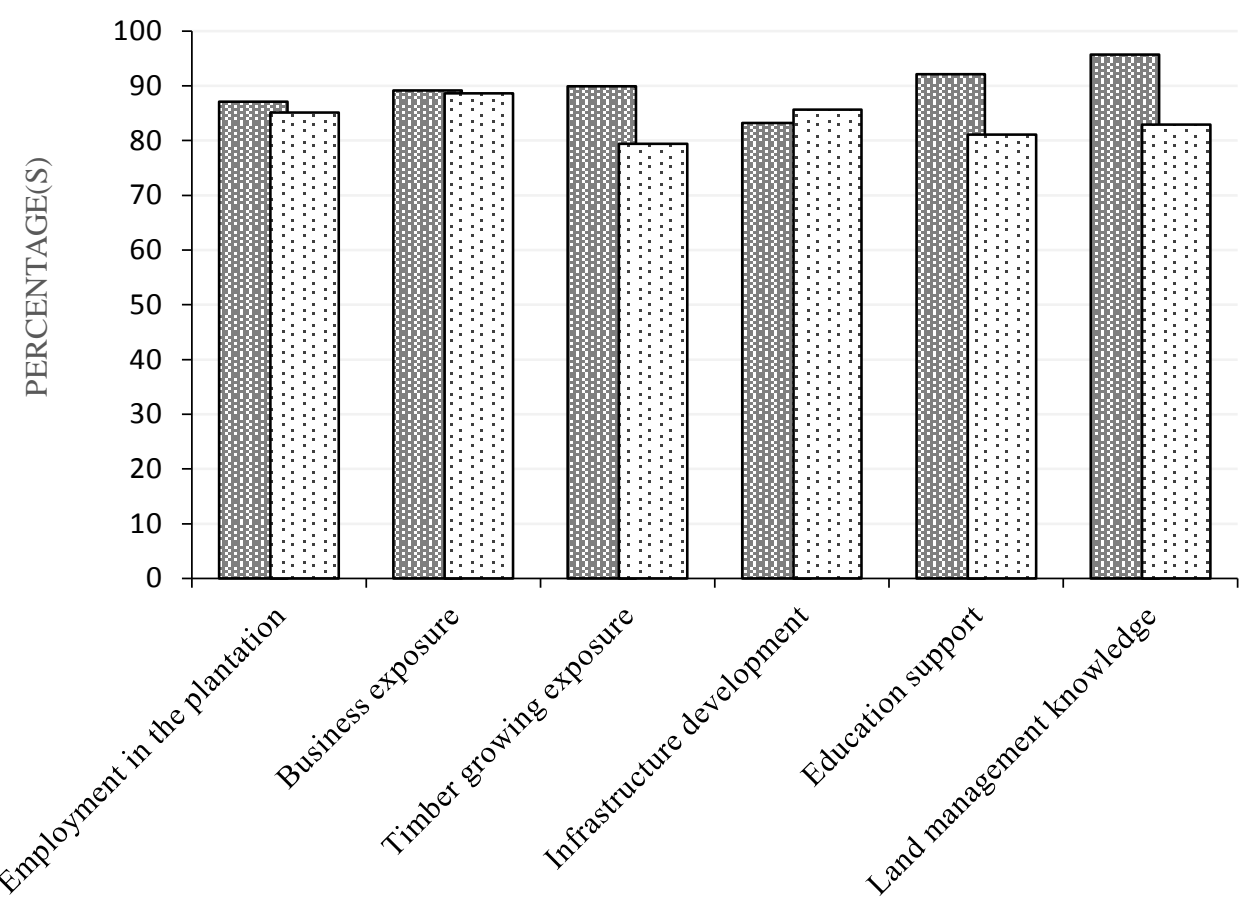

FIGURE 2: Household respondent's perceptions on the socioeconomic benefits that require more attention

\subsection{Rating of benefits received from partnership models}

Table 6 shows the rating of benefits obtained through the forest-based land reform partnership models. All the results on the rating of the socioeconomic benefits received were significant, including technical skills $\left(\chi^{2}=119.548 ; \mathrm{p}<0.001\right)$; employment in the plantation $\left(\chi^{2}=115.625\right.$; $\mathrm{p}<0.001)$; financial management skills $\left(\chi^{2}=117.866 ; \mathrm{p}<0.001\right)$; entrepreneur development $\left(\chi^{2}=107.052 ; \mathrm{p}<0.001\right)$; access to credit resources $\left(\chi^{2}=42.404 ; \mathrm{p}<0.001\right)$, and rental $\left(\chi^{2}=57.356 ; \mathrm{p}<0.001\right)$. The majority of the household respondents in Amabomvini simultaneously rated the benefit of employment in the plantation as bad (30.0\%) and very bad (56.4\%), compared to $19.4 \%$ (bad) and $10.3 \%$ (very bad) in Cata. Similarly, the financial management skill was rated poor, accounting for $27.9 \%$ (bad) and $67.1 \%$ (very bad) in Amabomvini compared to $37.1 \%$ (bad) and $12.6 \%$ (very bad) in Cata. These findings concurs 
with those from the focus group discussion wherein Cata CPA committee members emphasised that their objective has been to equitably distribute benefit to all the beneficiaries either financially and/or through creation of employment opportunities. On the other hand, the access to credit resources, as a result of the adopted partnership model, was rated very bad by both household respondents from Cata (40.2\%) and Amabomvini (72.1\%). Regarding the entrepreneurship development, fewer (16.2\%) household beneficiaries in Cata, compared to the majority (64.3\%) of those from Amabomvini, rated it very bad.

TABLE 6: Rating of socioeconomic benefits received due to forest-based land reform models

\begin{tabular}{|c|c|c|c|c|c|c|}
\hline \multirow[t]{2}{*}{ Benefits received by households } & \multirow[t]{2}{*}{ Rating } & \multicolumn{2}{|c|}{$\begin{array}{l}\text { Proportion of respondents }(\%) \text { in two } \\
\text { communities }\end{array}$} & \multicolumn{3}{|c|}{ Inferential statistics } \\
\hline & & $\begin{array}{l}\text { Amabomvini } \\
(\mathrm{n}=140)\end{array}$ & $\begin{array}{c}\text { Cata } \\
(\mathrm{n}=175)\end{array}$ & $\chi^{2}$ & df & $\begin{array}{c}\text { p- } \\
\text { value }\end{array}$ \\
\hline \multirow[t]{5}{*}{ Technical skills } & Excellent & 5.0 & 30.3 & & & \\
\hline & Good & 2.1 & 24.0 & & & \\
\hline & Average & 7.1 & 16.6 & 119.548 & 4 & 0.000 \\
\hline & Bad & 23.6 & 18.3 & & & \\
\hline & Very bad & 62.1 & 10.9 & & & \\
\hline \multirow[t]{5}{*}{ Employment in the plantation } & Excellent & 3.6 & 37.1 & & & \\
\hline & Good & 5.0 & 21.1 & & & \\
\hline & Average & 5.0 & 12.0 & 115.625 & 4 & 0.000 \\
\hline & $\mathrm{Bad}$ & 30.0 & 19.4 & & & \\
\hline & Very bad & 56.4 & 10.3 & & & \\
\hline \multirow{5}{*}{ Financial management skills } & Excellent & 1.4 & 13.1 & & & \\
\hline & Good & 1.4 & 18.3 & & & \\
\hline & Average & 2.1 & 18.9 & 117.866 & 4 & 0.000 \\
\hline & $\mathrm{Bad}$ & 27.9 & 37.1 & & & \\
\hline & Very bad & 67.1 & 12.6 & & & \\
\hline \multirow[t]{5}{*}{ Entrepreneur development } & Excellent & 2.9 & 12.1 & & & \\
\hline & Good & 1.4 & 20.2 & & & \\
\hline & Average & 1.4 & 23.7 & 107.052 & 4 & 0.000 \\
\hline & $\mathrm{Bad}$ & 30 & 27.7 & & & \\
\hline & Very bad & 64.3 & 16.2 & & & \\
\hline \multirow[t]{5}{*}{ Access to credit resources } & Excellent & 1.4 & 4.6 & & & \\
\hline & Good & 1.4 & 8.6 & & & \\
\hline & Average & 0.7 & 13.2 & 42.404 & 4 & 0.000 \\
\hline & Bad & 24.3 & 33.3 & & & \\
\hline & Very bad & 72.1 & 40.2 & & & \\
\hline \multirow[t]{5}{*}{ Rental } & Excellent & 1.4 & 4.0 & & & \\
\hline & Good & 4.3 & 18.4 & & & \\
\hline & Average & 0.7 & 10.3 & 57.356 & 4 & 0.000 \\
\hline & $\mathrm{Bad}$ & 22.9 & 36.8 & & & \\
\hline & Very bad & 70.7 & 30.5 & & & \\
\hline
\end{tabular}

\subsection{Effect of accrued benefits on the household socioeconomic status level}

A cumulative odds ordinal logistic regression with proportional odds was computed to predict accrued benefits that had a significant effect on the socioeconomic status of the household beneficiaries. The comparison of fitted model to a model with varying location parameters was assessed using a full likelihood ratio test and the results showed that there were proportional odds, $\chi^{2}(5)=5.474, p=0.361$. Furthermore, the pearson goodness-of-fit test revealed that the model fitted the observed data well, $\chi^{2}(37)=46.059, p=0.146$. Consequently, the results show that the prediction of dependent variable in the model was statistically significantly in addition 
to intercept only model, $\chi^{2}(5)=33.499, p<0.001$. The odds ratios of a household who observed change in socioeconomic status were highest for employment benefit accrual followed by bursary, nominated as trustee, finance and technical skills (Table 8). The change in socioeconomic status occurrences were highest in households that accrued employment benefit (odds ratio of $2.683,95 \%$ CI, 0.501 to 1.473 ) compared to those who did not. In addition, the odds ratio of 1.768 shows that the change in socioeconomic status of the household was more likely observed from those who accrued financial benefits than those who did not. According to the OLR results, it is clear that accrual of bursary (odds ratio 1.941, p > 0.05) as well as being nominated as trustee (odds ratio $1.834, \mathrm{p}>0.05$ ) benefits in the forest-based land reform PPP model do not significantly predict change in household beneficiaries' socioeconomic status. In addition to this finding, the FGD with the Amabomvini revealed that only four beneficiaries accrued bursaries and nomination as trustees. Similarly, the technical skills benefit accrual was statistically not significant to predict a change in socioeconomic status of the household beneficiaries, with odds ratio of $0.883, \mathrm{p}>0.05$.

TABLE 7: Model fitting and adequacy testing statistics

\begin{tabular}{|c|c|c|c|c|c|}
\hline Statistical Test & Model & -2 Log likelihood & Chi-square & df & Sig \\
\hline \multirow[t]{2}{*}{$\mathrm{a}$} & Intercept Only & 150.393 & & & \\
\hline & Final & 116.894 & 33.499 & 5 & .000 \\
\hline \multirow[t]{2}{*}{ b } & Pearson's & & 46.059 & 37 & 146 \\
\hline & Deviance & & 51.877 & 37 & .053 \\
\hline \multirow[t]{2}{*}{ c } & Null Hypothesis & 116.894 & & & \\
\hline & General & 111.420 & 5.474 & 5 & .361 \\
\hline
\end{tabular}

TABLE 8: The odds ratio estimates of forest-based land reform public-private partnership accrued benefits on household socioeconomic status change

\begin{tabular}{lcccc}
\hline Explanatory variables & Odds ratio & P-value & \multicolumn{2}{c}{ 95\% confidence interval for Odds ratio } \\
\cline { 4 - 5 } & & & Lower Bound & Upper Bound \\
\hline Employment benefit (yes) & 2.683 & 0.000 & .501 & 1.473 \\
Financial benefit (yes) & 1.768 & 0.811 & -.410 & .524 \\
Bursary benefit (yes) & 1.941 & 0.124 & -.182 & 1.508 \\
Nominated as a trustee (yes) & 1.834 & 0.132 & -.184 & 1.398 \\
Training skills benefit (yes) & 0.883 & 0.711 & -.783 & .534 \\
\hline
\end{tabular}




\section{DISCUSSION}

\subsection{Contribution of forest-based land reform PPP arrangements to household socioeconomic status}

The socioeconomic status of the beneficiaries in both communities, before and after implementation of the forest-based land reform PPP arrangement, reflected poor improvement. However, there is disparity in the level of improvement between the two communities owing to the forest-based land reform PPP arrangements that each community espoused for management of their land. For instance, contrary to the Amabomvini community, the household respondents in the Cata community indicated that their socioeconomic status continued to improve during the period after the land was transferred back to them. This trend could be linked to the desire and commitment expressed by the Cata CPA committee members during the focus group, which is to uplift every household beneficiary through various established land reform projects. Unlike Amabomvini community beneficiaries, who depended on rental and income generated through forestry contracting activity, the Cata CME model established three economic projects aimed towards substantially expanding on employment opportunities to the beneficiaries. In line with this finding, Peredo and Chrisman (2006) suggested that successes and frailties of the CME establishment depend upon its multipronged project approach, which exceed beyond land-based activities. Notwithstanding, other studies have reported that equitable distribution of the benefits across all the beneficiaries in various land reform projects remains a common challenge (Davis and Lahiff 2010).

The benefits accrued to each community provides a better picture of how the partnership arrangements have contributed to their livelihoods. In the case of Cata, the status of the households' beneficiaries changed because employment opportunities in the plantation accrued to a sizeable number of the beneficiaries. The reason for such an opportunity has been due to the commitment of the CPA committee members to create employment for all the beneficiaries. In addition, to achieve this high rate of job creation for the beneficiaries, the CPA committee members considered other initiatives being promoted by various government departments. In particular, the contribution of tourism and agricultural garden projects to supplement employment created through the forestry project also played a major role for the Cata community beneficiaries. As reported by Phillips (2013), it is important that both government and industry continue to work together to provide necessary and much needed support to the land reform beneficiaries. 
Additionally, the Amabomvini-Eyethu trustees highlighted the lack of post-settlement support from the government as their frustration. In the absence of government support, the challenge that the Amabomvini community beneficiaries usually encountered included poor administration guidance to the trustees, monitoring and evaluation of the partnership agreement, and limited financial resources to procure necessary inputs required to implement the partnership agreement with the private company. As such, these had negative impacts on improving the socioeconomic status of the beneficiaries. This is in line with the assertion of Moabelo (2007), that close monitoring and evaluation of projects emanating from land reform community projects by various government departments, is critical and recommended. Despite positive results achieved in the Cata community, their CPA committee members also emphasized unsatisfactory support from government at national, provincial and municipality level for not participating in the agreement of the claim settlement. In a bid to strengthen land reform in community institutions, FAO (2003) suggests that governments should remain committed to this endeavour by equipping beneficiaries with the relevant skills and support to manage commercial forestland.

\subsection{Benefits accrued to household beneficiaries from forest-based land reform PPP arrangements}

\subsubsection{Employment in the plantation and financial benefits}

The Land Reform Programme (LRP) brought about optimism amongst previously disadvantaged communities and government alike. For the government, the LRP provided an opportunity to reverse the atrocities experienced by the black majority under the apartheid regime (Puttergill et al. 2011). Through the LRP, the expectation was for the beneficiaries to harness the benefits from employment opportunities created by the implementation of various forest-based land reform partnership arrangements. However, contrasting realities of employment benefits in the plantation were recorded in the Amabomvini and Cata communities. According to the results, Cata household beneficiaries substantially accrued more employment in the plantation benefit in comparison to Amabomvini household beneficiaries.

Several studies strongly indicate that land claimants or community beneficiaries would require relevant government support in order to achieve socioeconomic benefits such as employment generation from their projects (Anseeuw and Mathebula 2008, Cousins and Aliber 2013, Lahiff et al. 2012). Similarly, Dlomo and Pitcher (2003) stated that people are more interested in employment benefits than forestland rental, sharing profit, land access and use rights benefits. 
Therefore, the differences between the two communities under study may be linked to the commitment of the community beneficiaries' legal entities (CPA/CT) and/or external stakeholders involved in the partnership arrangement to implement the programme that seeks to improve household beneficiaries' socioeconomic status. As highlighted by Lahiff (2007b), the improvement of the socioeconomic status of the beneficiaries of land reform may directly be from employment opportunities provided through profit sharing initiatives facilitated by Community Property Association (CPA) members or trustees. Nawir and Gumartini (2003) similarly emphasized that through partnership arrangements community beneficaires always stand an opportunity to benefit both employment and income. Although findings of this study revealed that beneficiaries from both the Amabomvini and Cata communities received financial benefits, this happened as a once-off direct payment of R2000 per household beneficiary in the year 2011 for the Amabomvini community and about R4400 in the year 2004 for the Cata community. In addition, the Ama-Bomnvini community trust accrued financial benefits from annual rentals and income generated from contracting opportunities. As revealed by Makhathini (2010), the decision on how to spend the income generated through rentals, was left completely to the trustees or community representatives on SLB partnership.

\subsubsection{Bursary and Technical Skills benefits}

The findings revealed that the investment towards capacity building through the provision of bursaries for formal education was low in the two communities under study. However, the beneficiaries in Cata, to a certain extent, indicated that they had benefited from funding for technical and financial management skills training. This support by the Cata CPA, through support from the Border Rural Committee (BRC), could be associated with their commitment to improve capacity in the management of their forestry project. As Baker (2014) suggests, the role of education as one of the measures of socioeconomic status, is important. While Mearns (2011) emphasized the significance of education in achieving success of any community project, Peter and Godsmark (2008) stressed the significance of the promotion of skills development opportunities for the youth and new forestry industry entrants. Through training interventions, the capacity of community beneficiaries to manage their land during project implementation stage could improve, and that may well contribute positively to their socioeconomic status. As highlighted by Adato et al. (2005), a long-term perspective on community skills development is vital, as this would enable communities to organize and manage their own resources. Without the necessary skills, it would not be easy to successfully manage the land transferred to the beneficiaries, neither would the partnership with private 
organizations be effective with regards to managing their land. According to Mearns (2011) most community projects would only become successful when beneficiaries are competent and have the necessary capacity to work and manage their project activities.

Consequently, the Cata community presented the household beneficiaries with substantive opportunities to harness technical skills from the forest plantation operations. As anticipated from the partnership agreement, attainment of the technical skills would enable land claimant beneficiaries to be more competent in the management of the forestry operations on their own (Nawir 2012, Ojwang 2000). As argued by Jacobson et al. (2008), it is important to make sure that technical and entrepreneurial skills as well as an understanding of economics principles are addressed, to prevent the the downfall of the project. Similarly, Johansson et al. (2012) emphasized the significance of technical skills for the successful management of communitybased projects. In addition, several authors, such as and Aliber and Cousins (2013), Bradstock (2005), DAFF (2010), Godsmark (2008) and Pogue (2008), postulate that the failure of community projects is often caused by factors such as a lack of business management, and technical and financial skills.

\subsubsection{Trust/CPA member nomination}

From this study, the majority of the respondents in Amabomvini indicated that they had not served in the Trust. Thus, in line with Stott (2012), it takes nomination of the few beneficiaries by the majority to play the role of managing the land on their behalf. As reported by Tilley and Lahiff (2007), trustees/CPA committee members are often the ones appointed as managers and/or decision makers, thereby receiving most of the financial benefits (income) while the majority of the interests of ordinary household beneficiaries are compromised. In support of this, and as outlined by Chamberlain and Anseeuw (2017), the trustees/CPA members often focus on accruing benefits to themselves at the expense of the majority. On the other hand, the Cata community respondents generally indicated that the opportunity of serving as a member of the CPA was equally presented to them all. Moreover, the element of elite capture in the leadership of the trust's management was more prominent in Amabomvini than in Cata, regrettably resulting even in the loss of life. In line with this finding, several studies reported that the failure to equally distribute the benefits and responsibilities to manage the claimed land amongst the beneficiaries has been attributed to the tendency of elite capture (Hall 2007, Godsmark 2008, Mearns 2011, White 2009). Accordingly, it is essential that the government engage with trustee/CPA members continuously, after the implementation of forest-based land 
reform partnership arrangements, in order to ensure that trustees and CPA committee members are adhering to their constitution.

\subsection{Influence of forest-based land reform models on benefit delivery}

Considering the benefits accrued to each of the two sampled community beneficiaries, it is evident that the beneficiaries from the Cata community substantially benefited when compared to those from the Amabomvini community. Faced with the responsibility of managing the land on behalf of the beneficiaries, the Cata CPA opened up more economic activities to ensure the active participation and involvement of the beneficiaries. Furthermore, the Cata CPA has also shown a commitment and willingness to create opportunities to deliver benefits to the beneficiaries. As reported by Coulibaly-Lingani et al. (2011), establishment of equitable benefit sharing approaches requires urgent attention in order to contribute to the participation and performance of the community beneficiaries in the management of land projects. On the contrary, Irimie and Essmann (2009) concluded that benefits to the people might not necessarily be influenced by efficiency or equity objectives of land reform, but rather by the implementation of proper processes and procedures that ensure delivery of benefits to the household beneficiaries. It may thus be deduced from the present study that the positive contribution of benefits delivery to the majority of household beneficiaries in Cata could be attributed to the CPA's willingness to create more opportunities for the members (Parliamentary Monitoring Group 2010). In fact, it has been reported by the Parliamentary Monitoring Group (2010) and the Centre for Law and Society in South Africa (2013), that land reform community projects operated under the management of CPAs, allow the government to intervene and resolve problems that may be encountered in the process.

On the other hand, the trustees of the Amabomvini Eyethu Trust managed the land that is leased back to the private company under the sales and leaseback forest-based partnership arrangement, and as a result, they received income on behalf of the beneficiaries from rental and stumpage fee payments. In addition, the Amabomvini Community Trust was assisted to register the Ingudle forestry contracting company as part of the agreement. Consequently, the private company prioritized all the contracting opportunities, including silvicultural operations, to the community beneficiaries' contracting company (Makhathini 2010, Chamberlain and Answeeuw 2017). However, the majority of respondents indicated their dissatisfaction with the lack of the benefits-sharing mechanisms within the current arrangement. Tilley and Lahiff (2007) and White (2009) have emphasized that the lack of benefits-sharing mechanisms in the community projects creates challenges and mistrust between community leadership and 
general beneficiaries. Subsequently, it would be important to ensure that benefits-sharing mechanisms are developed and made available to all the beneficiaries prior to the implementation of the partnership, to avoid any misunderstanding (Ashley and Ntshona 2003). Furthermore, an intervention from the government could be significant in assisting the negotiation and development of the benefits-sharing mechanisms in Public-Private Partnership (PPP) arrangements. For instance, the Amabomvini trustees highlighted their sentiments regarding the unfairness of the partnership, regardless of them having approved it. Both the trustees and general household beneficiaries agreed that the lease agreement should have included the component of the timber beneficiation amongst the benefits agreed upon. Manenzhe and Lahiff (2007) argue that the failure of land reform projects was often caused by irrelevant and poor planning during the initiation stage. Therefore, it is essential that community beneficiaries exhaust all the benefits expected from the lease back arrangement, prior to the finalization of the agreement.

Both the Amabomvini trustees and Cata CPA committee members highlighted that government had categorically failed to provide them with post-settlement support as promised in the land claim settlement agreement. The lack of such support from government could be attributed to its indecisive position with regard to whether land transferred to the claimant community should be managed under the CPA Act or the Trust Act. In addition, the lack of capacity within the land commission branch also resulted in the government failing to monitor and evaluate land reform community projects as planned (Gwanya 2010). Subsequently, the Border Rural Committee (2013) report proposed that government should prioritize the development of legislation that will strengthen the position of CPAs as the legally elected land-holding entity. Likewise, literature suggests that government intervention in the management of Public-Private Partnerships is critical as this could contribute to making sure that the interests of the community beneficiaries are protected (Manezhe and Lahiff 2007, Tilley et al. 2007, Underwood et al. 2007, White 2009).

\subsection{Accrued benefits predicting signficant household socioeconomic status}

As evidenced in the results, the effect of accrued employment benefits to the respondent's household socioeconomic status level was noticeable. The main argument that could be advanced in this study is that those respondents with members who have received employment benefits would generally be in a position to notice and indicate highest effect in their socioeconomic status. In agreement with these findings, some studies argued that employment benefit accruals (Bleyer et al. 2016, Rose 2000, Ofoegbu 2014), together with income and 
education are the driving factors of the household or individual member's socioeconomic status (Mabuza 2016). In this regard, it could be argued that CME forest-based land reform PPP model has more potential to improve community beneficiaries' socioeconomic status, as it was found to afford household beneficiaries with more employment opportunities than SLB. Interestingly, it was also observed that households that had members nominated as trustees and those with members that received technical skills did not automatically result in significant improvement of their socioeconomic status. Similarly, it was observed during the focus group discussion that not all the trustees accrued an equivalent amount of benefits, as they demonstrated contrasting knowledge and understanding of what was happening in the partnership. According to the literature, a handful of beneficiaries often accrue benefits while the majortity are compromised (Aliber and Cousins 2013, Chirwa et al. 2015, Mansuri and Rao 2004, Vega and Keenan 2016).

\section{CONCLUSION}

The findings of this study clearly reveal that the forest-based land reform PPP arrangements have not done enough to deliver the much-anticipated benefits to household beneficiaries. However, the accrual of benefits to households in both communities were markedly in contrast. On this note, the household beneficiaries from the Cata community highlighted they were enormously satisfied with their household socioeconomic status post-settlement of their land claim. As also evident in the Amabomvini community, a review of the Sales and Leaseback forest-based PPP land reform model agreement, in order to capture the component of beneficiation amongst the list of benefits that should accrue to the household beneficiaries, is paramount. In contrast, a sizeable number of household beneficiaries in Cata accrued benefits from their land to a certain extent under the CME forest-based PPP land reform arrangment. Notwithstanding, both communities emphasized the lack of post-settlement support promised to them by the government upon settlement of their land claims. Thus, the lack of such support had huge implications on the ability of both communities' legal entities to operate swiftly in their respective forest-based PPP land reform arrangments. The silence of the government regarding the long outstanding promised discretionary grants has left the communities dissatisfied and feeling setup into engaging with these Public-Private Partnerships.

Consequently, it would be of great significance for the government to consider strengthening the necessary support required to represent the interests of the community beneficiaries in the forged Public-Private Partnership. Put simply, this means that the government would have to 
play a central role in dictating equitable shares of the benefits expected to accrue to the household beneficiaries from the adopted forest-based PPP land reform models by implementing relevant policies, including specifically benefit-sharing and beneficiation. Furthermore, it would be essential for the government to also provide post-settlement support timeously as indicated in the settlement agreement. This support should include monitoring and evaluation of the initiated forest-based PPP, early disbursement of settlement grants, and provision of capacity building programmes, specifically tailor-made training for the forestry land reform beneficiaries, since this could improve benefits to the household. Additionally, the private company should carry similar responsibilities to expedite transformation of the socioeconomic status of the household beneficiaries. Most importantly, the development of mutual benefit-sharing mechanisms should be transparent and transformative enough to consider the ideas of household beneficiaries. As such, this study recommends a research study to determine the desired benefit-sharing modalities of land claimant beneficiaries. Additionally, the study to assess the long-term impact of forest-based land reform PPP partnership models in both communities on household's socioeconomic status will be significant.

\section{ACKNOWLEDGEMENTS}

The authors would like to extend our greatest appreciation to all the funding institutions, including the South African Forest Company Limited (SAFCOL) and National Research Foundation (NRF). In addition, we acknowledge the support that the Community Trust in Amabomvini and the Communal Property Association in Cata provided during our survey in their localities.

\section{REFERENCES}

ADATO, M., HODDINOTT, J. and HADDAD, L., 2005. Power, Politics, and Performance: Community Participation in South African Public Works Programs (Vol. 143). International Food Policy Research Institute.

ALIBER, M. AND COUSINS, B. 2013. Livelihoods after land reform in South Africa. Journal of Agrarian Change 13(1): 140-165.

ALIBER, M. and MALULEKE, T. 2010. The role of "black capital" in revitalising land reform in Limpopo, South Africa. Institute for Poverty, Land and Agrarian Studies (PLAAS), University of the Western Cape 
ALLEN, I.E. and SEAMAN, C.A. 2007. Likert scales and data analyses. Quality Progress 40(7): 64-65.

ANC (African National Congress), 1994. The reconstruction and development programme: A policy framework.

ANSEEUW, W. and MATHEBULA, N. 2008. Evaluating land reform's contribution to South Africa's pro-poor growth pattern. South Africa's economic miracle-has the emperor lost his clothes? Annual Forum.

ASHLEY, C. and NTSHONA, Z. 2003. Transforming roles but not reality? Private sector and community involvement in tourism and forestry development on the Wild Coast, South Africa. Research Paper 6.

BAKER, E. H. 2014. Socioeconomic status, definition. The Wiley Blackwell Encyclopedia of Health, Illness, Behaviour, and Society. 2210-2214.

BHATTACHERJEE A. 2012. Social science research: principles, methods, and practices.

BLEYER, M., KNIIVILÄ, M., HORNE, P., SITOE, A. AND FALCÃO, M.P. 2016. Socioeconomic impacts of private land use investment on rural communities: Industrial forest plantations in Niassa, Mozambique. Land Use Policy 51: 281-289.

BORDER RURAL COMMITTEE, 2013. Six Monthly Report. January to June. East London. South Africa.

BRADSTOCK, A. 2005. Changing livelihoods and land reform: Evidence from the Northern Cape province of South Africa. World Development 33(11): 1979-1992.

BRITTON, P.E.N. 2006. A short history of forestry in South Africa. https://www.sanparks.org/parks/table_mountain/library/2006/tokai_cecilia/annexC.pdf

Accessed on 09 April 2018

CENTRE FOR LAW and SOCIETY, 2013. Restitution of Land Rights Amendment Bill. Rural Women's Research Programme.

CHAMBERLAIN, W.O. and ANSEEUW, W. 2017. Contract farming as part of a multiinstrument inclusive business structure: A theoretical analysis. Agrekon 1-15.

CHIRWA, P.W., MAMBA, S., MANDA, S.M. and BABALOLA, F.D. 2015. Assessment of settlement models for engagement of communities in forest land under claim in Jessievale and Roburna communities in Mpumalanga, South Africa. Land Use Policy Journal 46:6574.

CLARKE, J. 2008. Trends in forest ownership, forest resources tenure and institutional arrangements in South Africa: Are they contributing to better forest management and 
poverty reduction? Case study from South Africa. In: FAO. 2008. Understanding forest tenure in Africa: opportunities and challenges for forest tenure diversification./Comprendreles Régimes forestiers en Afrique: opportunités et enjeux de diversification. Forestry Policy and Institutions Working Paper/Document du travail sur les politiques et les institutions forestières No. 19. Rome.

CLARKE, J. and ISAACS, M. 2005. Forestry contractors in South Africa: what role in reducing poverty? Programme for Land and Agrarian Studies, University of the Western Cape, South Africa, and International Institute for Environment and Development, London, UK.

COULIBALY-LINGANI, P., SAVADOGO, P., TIGABU, M. and ODEN, P.C. 2011. Factors influencing people's participation in the forest management program in Burkina Faso, West Africa. Forest Policy and Economics 13(4): 292-302.

COUSINS, B. and ALIBER, M. 2013. Unworkable land reform project designs offer inappropriate farming models to rural dwellers. Institute for Poverty, Land and Agrarian Studies (PLAAS), University of the Western Cape

DAFF, 2010. Annual report on the status of agricultural co-operatives. Republic of South Africa.

DAMNYAG, L., SAASTAMOINEN, O., APPIAH, M. and PAPPINEN, A. 2012. Role of tenure insecurity in deforestation in Ghana's high forest zone. Forest Policy and Economics 14(1): 90-98.

DAVIS, N. and LAHIFF, E. 2010. Joint ventures in South Africa's land reform programme: strategic partnerships or strategic resource grab? Paper presented to the Global Land Grabbing conference, Brighton, 6-8th April 2010.

DE WET, C. 1997. Land reform in South Africa: A vehicle for justice and reconciliation, or a source of further inequality and conflict? Development Southern Africa 14(3): 355-62.

DLA (Department of Land Affairs), 1997. White paper on South African land policy. Republic of South Africa.

DLOMO, M. and PITCHER, M. 2003. Changing ownership and management of state forest plantations: South African's experience. International conference on changing ownership and management of stated forest plantation: issues, approaches, implementation. Cape Town, South Africa, 06-08 November 2002.

DWAF, 2005. Draft key issue paper on forestry and poverty in South Africa.

DWAF, 2007. Forest sector transformation charter: first draft for presentation to stakeholders. 
FAO, 2003. Forestry outlook study for Africa: regional report, opportunities and challenges towards 2020. FAO forestry paper. Issue 141.

GODSMARK, R., 2008. Forestry land reform post-settlement support models. Pietermaritzburg, Forestry South Africa.

GRIEJMANS, M., TRIRAGANON, R. and GRITTEN, D. 2014. Fundamentals of viable community forestry business models: Preliminary research findings. Working paper presented at the $24^{\text {th }}$ IUFRO World Congress, Salt Lake City, Utah, USA.

GWANYA, T. 2010. Briefing to the portfolio committee on rural development and land reform: The state of the community property association and other legal entities for land reform projects. Parliament, 3rd March. Cape Town

HALL, R. 2004. A political economy of land reform in South Africa. Review of African Political Economy 31(100): 213-27.

HALL, R. 2007. The impact of land restitution and land reform on livelihoods. Research report 32. PLAAS, University of Western Cape.

HALL, R. 2009. A fresh start for rural development and agrarian reform? Policy brief 29. PLAAS, University of Western Cape.

HAM, C. and CHIRWA, P.W. 2007. Forestry and poverty: raising the contribution / profile offorestry to rural development. Report compiled for the FAO National Forest Programme Facility and the Department of Water Affairs and Forestry. University of Stellenbosch, South Africa

HEDMAN, J., LIND, M., FORSGREN, O. and ALBINSSON, L. 2008. Business Models for Public Private Partnership: The 3P Framework. IOS Press.

IRIMIE, D.L. and ESSMANN, H.F. 2009. Forest property rights in the frame of public policies and societal change. Forest Policy and Economics 11(2): 95-101.

JACOBSON, M.G., HAM, C. and ACKERMAN, P.A. 2008. Forest management educational needs in South African forestry companies. Southern Forests: a Journal of Forest Science 70(3): 269-274.

JOHANSSON, K.E., GONDO, P., NANTONGO, C., ROOS, A. and KLEINSCHMIT, D. 2012. Empowering community based forest and tree user and producer groups: an outlook study of stakeholder groups in the management and use of forest and tree resources in Ethiopia, Kenya, Uganda, Tanzania and Zambia.

KELLEY, K., CLARK, B., BROWN, V. and SITZIA, J. 2003. Good practice in the conduct and reporting of survey research. International Journal for Quality in health care 15(3): 261-266. 
KREJCIE, R.V. and MORGAN, D.W. 1970. Determining sample size for research activities. Educational and psychological measurement 30(3): 607-610.

LAHIFF, E. 2007a. 'Willing buyer, willing seller'. South Africa's failed experiment on marketled agrarian reform. The Third World Quarterly 28(8): 1577-1597.

LAHIFF, E. 2007b. Business models in land reform. Institute for Poverty, Land and Agrarian Studies (PLAAS), University of the Western Cape.

LAHIFF, E., DAVIS, N. and MANENZHE, T. 2012. Joint ventures in agriculture: lessons from land reform projects in South Africa. IIED/IFAD/FAO/PLAAS, London/Rome/Cape Town.

MABUZA, N. 2016. Socio-economic impact of land reform projects benefiting from the Recapitalisation and Development Programme in South Africa(No. 243471). Collaborative Masters Program in Agricultural and Applied Economics.

MAKHANYE, T. 2013. The impact of the Natives' Land Act on spatial patterns and settlements in South Africa. Research unit, Parliament of the Republic of South Africa.

MAKHATHINI, M. 2010. Mondi "Sales and Leaseback" model in South Africa. In: COTULA, L. and LEONARD, R. 2010 (ed.) Alternatives to land acquisitions: agricultural investment and collaborative business models: highlights from an international lesson-sharing workshop (Maputo, 17th-18th March 2010). IIED.

MANENZHE, T. and LAHIFF, E. 2007. Restitution and post-settlement support: three case studies from Limpopo. Research report 39. Programme for Land and Agrarian Studies.

MANSURI, G. and RAO, V. 2004. Community-based and-driven development: A critical review. The World Bank Research Observer 19(1): 1-39.

MAYERS, J. and VERMEULEN, S. 2002. Company-community forestry partnerships: From raw deals to mutual gains? Instruments for sustainable private sector forestry series. International institute for Environment and Development, London.

MCMENAMIN, V. 2009. Chairperson's report 2008. Forestry South Africa [Accessed on 27 December 2012].

MEARNS, K.F. 2011. Ekaluka farmers association and land reform programme: Expectations and success factors. Development Southern Africa 28(2): 241-54.

MOABELO, K.E. 2007. The land claim process in Limpopo province: A case study of the Mokotopong community, South Africa. MSc Theses. University of Pretoria.

MOUTINHO, L. and HUTCHESON, G.D. 2011. The sage dictionary of quantitative management research. First Edition. Business and Management. Sage. 
NAWIR, A.A. and GUMARTINI, T., 2003. Company-community partnership outgrower schemes in forestry plantations in Indonesia: an alternative to conventional rehabilitation programmes. In Bringing back the forests: policies and practices for degraded lands and forests. Proceedings of an international conference, 7-10 October 2002, Kuala Lumpur, Malaysia. FAO Regional Office for Asia and the Pacific, Bangkok, Thailand.

NAWIR, A.A., 2012. Towards commercially oriented community forestry management: coping with economic globalization and commercialization. IUFRO proceedings, pp.114123.

OFOEGBU, C. 2014. The contribution of tree plantations to household welfare: case study of Piet Retief and Iswepe. International Forestry Review 16(2): 172-179.

OJWANG, A., 2000. Community-company partnerships in forestry in South Africa-An examination of trends. IIED \& CSIR.

PARLIAMENTARY MONITORING GROUP, 2010. Communal Property Associations, trusts and other land holding legal entities: Rural Development and Land Reform Department's briefing. Portfolio committee meeting minutes. https://pmg.org.za/committee-meeting/11281/ Accessed on 18 July 2016.

PEPETEKA, T. 2013. Reversing the Legacy of the 1913 Natives Land Act: Progress of Land Reform. Research unit, Parliament of the Republic of South Africa.

PEREDO, A.M. and CHRISMAN, J.J., 2006. Toward a theory of community-based enterprise. Academy of management Review, 31(2), pp.309-328.

PETER, M. and GODSMARK, R. 2008. Future trends in forestry industry and implications for skills development. Forestry Industry Skills Forum Meeting. Durban, $20^{\text {th }} \& 21^{\text {st }}$ August. Forestry South Africa.

PHILLIPS, L. 2013. Public/private alliance critical for successful land reform. Land Reform and Rural Development with the South African Sugar Association. Farmers weekly.

POGUE, T.E. 2008. Sectoral analysis of wood, paper, pulp industries in South Africa. Research commissioned by Department of Labour. South Africa.

PUTTERGILL, C., BOMELA, N., GROBBELAAR, J. and MOGUERANE, K. 2011. The limits of land restitution: Livelihoods in three rural communities in South Africa. Dev. South. Afr. 28: 597-611. https://doi.org/10.1080/0376835X.2011.623921

ROSE, D. ed., 2000. Researching social and economic change: the uses of household panel studies (Vol. 12). Psychology Press.

RSA (Republic of South Africa), 1994. White paper on Reconstruction and Development Programme. Government Gazette. 
RUMNEY, R., 2005. Who Owns South Africa: An Analysis of State and Private Ownership Patterns-State of the Nation 2004-2005.

SHAHEEN, F.H. and KHAN, S.R., 2008. Public-Private Partnerships (PPP) in Forestry: Implementing Strategy. Project report series (12). Sustainable Development Policy Institute.

SIKOR, T. and MÜLLER, D. 2009. The limits of state-led land reform: an introduction, World Development 37(8): 1307-1316.

STOTT, F. 2012. Trusts: a basic guide. Attorneys, Nataries and Conveyancers Newsletter 3 http://www.fouriestott.co.za/wp-content/uploads/2012/03/Newsletter-3-2012-Website.pdf Accessed on 18 July 2016.

TILLEY, S. and LAHIFF, E. 2007. Bjatladi community restitution claim. Institute for Poverty, Land and Agrarian Studies.

TILLEY, S., NKAZANE, N. and LAHIFF, E. 2007. Groenfontein-Ramohlakane community restitution claim. Institute for Poverty, Land and Agrarian Studies.

UNDERWOOD, M., BLAKEWAY, F., KHUMALO, P., LÄNGIN, D., LOUW, J. and MACK, R. 2007. South African forestry, integrating the first and second economies: a curriculum template for African forestry. In: An Invited Presentation given at the First Global Workshop on Forest Education, Nairobi.

VAN LOGGERENBERG, C. and MANDONDO, A. 2008. A study of outgrower forestry in Southern Natal, exploring practice, perceptions, and prospects for SAPPI Project Grow.

VEGA, D.E.C. and KEENAN, R.J. 2016. Situating community forestry enterprises within New Institutional Economic theory: What are the implications for their organization? Journal of Forest Economics 25: 1-13.

WHITE, R. 2009. Tribal land administration in Botswana. Policy Brief 31. Institute for Poverty, Land and Agrarian. 